Article 21

The original of the present Convention, of which the Arabic, Chinese, English, French, Russian and Spanish texts are equally authentic, shall be deposited with the Secretary-General of the United Nations, who shall send certified copies thereof to all States.

In witness whereof the undersigned, being duly authorized thereto by their respective Governments, have signed the present Convention.

\title{
International Peace Operations Association (IPOA) Code of Conduct ${ }^{1}$
}

\section{Preamble: Purpose}

This Code of Conduct seeks to ensure the ethical standards of International Peace Operations Association member companies operating in conflict and post-conflict environments so that they may contribute their valuable services for the benefit of international peace and human security.

Additionally, Signatories are encouraged to follow all rules of international humanitarian law and human rights law that are applicable as well as all relevant international protocols and conventions, including but not limited to:

- Universal Declaration of Human Rights (1948)

- Geneva Conventions (1949)

- Convention Against Torture (1975)

- Protocols Additional to the Geneva Conventions (1977)

- Chemical Weapons Convention (1993)

- Voluntary Principles on Security and Human Rights (2000) Members of IPOA are pledged to the following principles in all their operations:

\section{Human Rights}

1.1. In all their operations, Signatories will respect the dignity of all human beings and strictly adhere to all relevant international laws and protocols on human rights.

1.2. In all their operations, Signatories will take every practicable measure to minimize loss of life and destruction of property.

\section{Transparency}

2.1. Signatories will operate with integrity, honesty and fairness.

2.2. Signatories engaged in peace or stability operations pledge, to the extent possible and subject to contractual and legal limitations, to be open and forthcoming with the International Committee of the Red Cross and other relevant authorities on the nature of their operations and any conflicts of interest that

1 http://ipoaworld.org/eng/codeofconductv11eng.html might in any way be perceived as influencing their current or potential ventures.

\section{Accountability}

3.1. Signatories understand the unique nature of the conflict/ post-conflict environment in which many of their operations take place, and they fully recognize the importance of clear and operative lines of accountability to ensuring effective peace operations and to the long-term viability of the industry.

3.2. Signatories support effective legal accountability to relevant authorities for their actions and the actions of company employees. While minor infractions should be proactively addressed by companies themselves, Signatories pledge, to the extent possible and subject to contractual and legal limitations, to fully cooperate with official investigations into allegations of contractual violations and violations of international humanitarian law and human rights law.

3.3. Signatories further pledge that they will take firm and definitive action if employees of their organization engage in unlawful activities.

\section{Clients}

4.1. Signatories pledge to work only for legitimate, recognized governments, international organizations, non-governmental organizations and lawful private companies.

4.2. Signatories refuse to engage any unlawful clients or clients who are actively thwarting international efforts towards peace.

4.3. Signatories pledge to maintain the confidentiality of information obtained through services provided, except when doing so would jeopardize the principles contained herein.

\section{Safety}

5.1. Recognizing the often high levels of risk inherent to business operations in conflict/post-conflict environments, Signatories will always strive to operate in a safe, responsible, consci- 
entious and prudent manner and will make their best efforts to ensure that all company personnel adhere to these principles

\section{Employees}

6.1. Signatories ensure that all their employees are fully informed regarding the level of risk associated with their employment, as well as the terms, conditions, and significance of their contracts.

6.2. Signatories pledge to ensure their employees are medically fit, and that all their employees are appropriately screened for the physical and mental requirements for their applicable duties according to the terms of their contract.

6.3. Signatories pledge to utilize adequately trained and prepared personnel in all their operations in accordance with clearly defined company standards.

6.4. Signatories pledge that all personnel will be vetted, properly trained and supervised and provided with additional instruction about the applicable legal framework and regional sensitivities of the area of operation.

6.5. Signatories pledge that all their employees are in good legal standing in their respective countries of citizenship as well as at the international level.

6.6. Signatories agree to act responsibly and ethically toward all their employees, including ensuring employees are treated with respect and dignity and responding appropriately if allegations of employee misconduct arise.

6.7. Where appropriate, signatories should seek employees that are broadly representative of the local population.

6.8. Payment of different wages to different nationalities must be based on merit and national economic differential, and cannot be based on racial, gender or ethnic grounds.

6.9. In the hiring of employees engaged in continuous formal employment, signatories agree to respect the age-minimum standard of 15 years of age as defined by the International Labor Organization Minimum Age Convention (1973).

6.10. No employee will be denied the right to terminate their employment. Futhermore, no signatory may retain the personal travel documents of its employees against their will.

6.11. Signatories agree to provide all employees with the appropriate training, equipment, and materials necessary to perform their duties, and to render medical assistance when needed and practical.

6.12. Employees will be expected to conduct themselves humanely with honesty, integrity, objectivity, and diligence.

\section{Insurance}

7.1. Foreign and local employees will be provided with health and life insurance policies appropriate to their wage structure and the level of risk of their service as required by law.

\section{Control}

8.1. Signatories strongly endorse the use of detailed contracts specifying the mandate, restrictions, goals, benchmarks, criteria for withdrawal and accountability for the operation.

8.2. Contracts shall not be predicated on an offensive mission unless mandated by a legitimate authority in accordance with international law.

8.3. In all cases-and allowing for safe extraction of personnel and others under the Signatories' protection-Signatories pledge to speedily and professionally comply with lawful requests from the client, including the withdrawal from an operation if so requested by the client or appropriate governing authorities.

\section{Ethics}

9.1. Signatories pledge to go beyond the minimum legal requirements, and support additional ethical imperatives that are essential for effective security and peace related operations:

\subsection{Rules of Engagement}

9.2.1. Signatories that could potentially become involved in armed hostilities will have appropriate "Rules of Engagement" established with their clients before deployment, and will work with their client to make any necessary modifications should threat levels or the political situation substantially change.

9.2.2. All Rules of Engagement should be in compliance with international humanitarian law and human rights law and emphasize appropriate restraint and caution to minimize casualties and damage, while preserving a person's inherent right of self-defense. Signatories pledge, when necessary, to use force that is proportional to the threat.

\subsection{Support of International Organizations and NGOs/ Civil Society and Reconstruction}

9.3.1. Signatories recognize that the services relief organizations provide are necessary for ending conflicts and alleviation of associated human suffering.

9.3.2. To the extent possible and subject to contractual and legal limitations, Signatories pledge to support the efforts of international organizations, humanitarian and non-governmental organizations and other entities working to minimize human suffering and support reconstructive and reconciliatory goals of peace operations.

\subsection{Arms Control}

9.4.1. Signatories using weapons pledge to put the highest emphasis on accounting for and controlling all weapons and ammunition utilized during an operation and for ensuring their legal and proper accounting and disposal at the end of a contract.

9.4.2. Signatories refuse to utilize illegal weapons, toxic chemicals or weapons that could create long-term health problems or complicate post-conflict cleanup and will limit themselves to appropriate weapons common to military, security, or law enforcement operations. 


\section{Partner Companies and Subcontractors}

10.1. Due to the complex nature of the conflict/post-conflict environments, companies often employ the services of partner companies and subcontractors to fulfill the duties of their contract.

10.2. Signatories agree that they select partner companies and subcontractors with the utmost care and due diligence to ensure that they comply with all appropriate ethical standards, such as this Code of Conduct.

10.3. The future of the peace operations industry depends on both technical and ethical excellence. Not only is it important for IPOA member companies to adhere to the principles expressed in this Code, each member should encourage and support compliance and recognition of the Code across the industry.

\section{Application}

11.1. This Code of Conduct is the official code of IPOA and its member organizations. Signatories pledge to maintain the standards laid down in this Code.

11.2. Signatories who fail to uphold any provision contained in this Code may be subject to dismissal from IPOA at the discretion of the IPOA Board of Directors.

11.3. Member companies will endeavor to impart the basic principles of the IPOA Code of Conduct to their employees.

\section{Version: 11}

Adopted: December 1, 2006

Code of Conduct First Adopted: April 1, 2001

\title{
Neue Theorieansätze in der Friedens- und Konfliktfor- schung - Zweiter Workshop des AK Theorie der AFK
}

\section{Tagungsbericht}

\author{
Maurice Herchenbach ${ }^{1}$
}

Im Rahmen der Workshop-Reihe des Arbeitskreises Theorie der Arbeitsgemeinschaft für Friedens- und Konfliktforschung fand das zweite Arbeitstreffen vom 10. bis 12. April 2008 auf Schloss Rauischholzhausen bei Marburg statt. Wie zuvor im Juli 2007 fanden sich erneut zahlreiche Friedens- und KonfliktforscherInnen zusammen, die aus philosophischer, sprachwissenschaftlicher, soziologischer und politikwissenschaftlicher Perspektive neue Theorieansätze vorstellten und diskutierten (siehe die Homepage des Arbeitskreises unter http://www.uni-marburg.de/konfliktforschung/aktheorie).

Im Anschluss an die Eröffnung des Workshops skizzierte Christoph Weller einführend drei Dimensionen, entlang derer neue Entwicklungen erfasst werden können:

- Das frühere Ideal der friedenswissenschaftlichen Interdisziplinarität wird zunehmend von einer Multidisziplinarität abgelöst, die sich durch Eingebundenheit in eine „Hausdisziplin " und den intensiven Austausch zwischen den Disziplinen auszeichnet.

- Zahlreiche neue Gegenstände, die vor einigen Jahren noch wenig relevant erschienen, sind in den Forschungsfokus gerückt (z.B. Terrorismus, Friedenskonsolidierungsprozesse, fragile Staatlichkeit).

- Mit dem gestiegenen Einfluss der Friedens- und KonfliktforscherInnen auf die Politik, wie sich $u$. a. beim Zivilen Friedensdienst aber auch beim Demokratisierungsdiktum gezeigt hat, ist auch die Pflicht und Verantwortung zur eigenen Interventionsbeobachtung und -reflexion deutlich gestiegen.

1 Dipl.-Pol., Arbeitsbereich Internationale Friedens- und Sicherheitspolitik, Freie Universität Berlin.
Der Workshop begann mit einem Beitrag von Gertrud Brücher zu „Eskalation als Gewalt- und Friedensparadigma“. Darin unternimmt die Autorin den Versuch, Gewalt konzeptionell als Wechselwirkung zu erfassen, wobei sie unter Wechselwirkung Prozesse versteht, in denen sich Gewalt autopoietisch reproduziert. Wo Wechselwirkungen entstehen, verschwinden laut Brücher die Akteure der Gewalt. Gerade solche Gewalt aber sollte als zentrales Problem der Friedens- und Konfliktforschung erfasst werden, da für diese Gewaltprozesse bislang keine Deutungsmuster vorhanden sind. Eine herkömmliche, akteurszentrierte theoretische Perspektive, die weiterhin von der Unterscheidbarkeit von Tätern und Opfern ausgeht, ist Brücher zufolge nicht in der Lage zu erfassen, wo und wann vermeintlich nützliche Gewalt (aus der Perspektive der Akteure) eskaliert und nichtintendierte Effekte hervorbringt.

Zahlreiche Diskussionsbeiträge problematisierten die Definition von Konflikt als gewalthaltige Extremsituation, weil durch sie theoretische Erkenntnisse und praktische Nutzbarmachungen ausgeblendet würden, die auf einem Verständnis von Konflikt als Normalfall menschlicher Interaktion basierten. Vor diesem Hintergrund wurde die Frage gestellt, ob ein solcher Konfliktbegriff für die Friedenstheorie ausreiche. Darüber hinaus wurde festgestellt, dass ein systemtheoretischer Ansatz hinsichtlich des Verständnisses komplexer Konfliktsysteme zwar analytisches Potential besitze, gleichzeitig aber die Erkenntnisse der akteurszentrierten, sozialwissenschaftlichen Konfliktforschung nicht völlig vernachlässigt werden sollten.

Der Beitrag von Jörg Lehmann zu „Hate Speech in den Medien“ untersucht aus sprachtheoretischer Perspektive das Phänomen von Hassreden am Beispiel der Botschaften Osama bin Ladens. 